\title{
FOGYATÉKOSSÁGGAL ÉLŐ SZEMÉLYEK SPORTOLÁSÁVAL FOGLALKOZÓ SPORTSZERVEZET KOMMUNIKÁCIÓS SAJÁTOSSÁGAINAK VIZSGÁLATA
}

\author{
Laoues-Czimbalmos Nóra - Müller Anetta - Bácsné Bába Éva
}

\begin{abstract}
Absztrakt: A vezetői munka kulcsfontosságú eleme a hatékony kommunikáció. Mintzberg (1988) kutatásainak eredményei alapján kijelenthető, hogy a vezetők munkájuk során, idejük nagy részét az információk közlésével, fogadásával, rendszerzésével töltik túlnyomó részben. A vezetésben résztvevőknek rendelkezniük kell a következő tulajdonságokkal: személyes megfelelés, rátermettség, kölcsönös felelösségvállalás (Juhász, 2012). A személyes vezetés legfontosabb tényezői: a hatékony személyközi kommunikáció, megfelelő vezetési stílus megválasztása és alkalmazása, a személyzeti menedzsment eszköztárának gyakorlása, amelyen belül kiemelten fontos a beosztottak motivációja ösztönzésének módja (Juhász, 2012). A kutatásban fogyatékossággal élő személyek sportolásával foglalkozó sportszervezet szervezeti kommunikációs és motivációs sajátosságait vizsgáltuk.
\end{abstract}

Abstract: Effective communication is a key element of leadership work. According to the results of research carried out by Mintzberg (1988), the managers spend most of their time in communicating, receiving and systematizing information in their work. Driving participants must have the following characteristics: personal compliance, fitness, mutual responsibility (Juhász, 2012). The most important factors of personal leadership are: effective interpersonal communication, the choice and use of a suitable management style, the exercise of the personnel management toolkit, in which the motivation of motivated employees is of particular importance (Juhász, 2012). I will examine the organizational communication and motivational features of the sports organization of people with disabilities in the research.

Kulcsszavak: kommunikáció, motiváció, fogyatékossággal élő személyek

Keywords: communication, motivation, disabilities

\section{Bevezetés}

A WHO és a Világbank (2011) felmérése szerint a fogyatékossággal élő személyek száma a világban emelkedő tendenciát jelez, e szerint a korábbi 10\%-os arány helyett ma már a világ lakosságának 15\%-át érintő problémáról beszélhetünk. A Központi Statisztikai Hivatal (2014) mérése szerint Magyarország tekintetében a fogyatékos személyek száma 2001-ben 577 ezer fö volt, ami a lakosság 5,7\%-át teszi ki. A 2011es népszámlálás során 490578 személy, a népesség közel 5\%-a élt fogyatékossággal. Fogyatékossági típusok szerint a mozgássérültek vannak a legtöbben 47\% 232 ezer fö. A gyengénlátók a második legnagyobb csoportot alkotják 15\%-ban 73 ezren, a harmadik legnagyobb csoport a nagyothallók 13\% 63 ezer fö. A súlyos belszervi fogyatékossággal élők (10\%), a mentálisan sérültek (9\%) és az értelmi fogyatékosok (9\%). A beszédhibások $2 \%$-ot, a beszédfogyatékosok 2\%-ot, a vakok $2 \%$-ot, a siketek 1\%-ot, az autisták és a siketvakok szintén 1\%-ot tesznek ki. A népesség kevesebb mint 1\%-nak egyéb fogyatékossága van.

A fogyatékossággal élők vagy a megváltozott munkaképességü személyekre fókuszáló kutatások napjainkban vettek lendületet (Balázs-Földi-Dajnoki 2016a; Balázs-Földi-Dajnoki 2016b; Balázs-Földi, 2017), éppen ezért nem képeznek olyan 
teljességre törő rendszert és nem olyannyira átfogóak, mint az épekkel foglalkozó szakirodalmak.

A fogyatékossággal élök sportolását vizsgáló hazai (Osváth, 2004; Sáringerné, 2014; Lőrincz et al., 2015; Laczkó-Rétsági 2015; Gombás 2016; Tóthné-Gombás 2016) és nemzetközi (LeMura 2002; Frey et al., 2008; Carlon et al., 2013; Johnson, 2009; Block et al., 2013; Shapiro-Martin, 2016; Bota et al., 2014; Kissow et al., 2015; Oktay et al., 2015) szakirodalmak száma szintén korlátozott számban érhető el.

A kutatásunkban a hazai fogyatékos személyek sportolásával foglalkozó szervezetek képezték a vizsgálatunk tárgyát. A szervezetekben dolgozó vezetők kommunikációs készségeit helyeztem a vizsgálatom középpontjába.

A legfontosabb vezetöi készségek között vannak a konceptuális, a kommunikációs, az interperszonális és a szakmai készségek, amelyek a különböző szintü vezetőknek igen fontos az eredményesség szempontjából (Stocker et al., 2015). Lásd: 1. ábra.

\section{1. ábra: A vezetői készségek Nemes (2006) alapján}

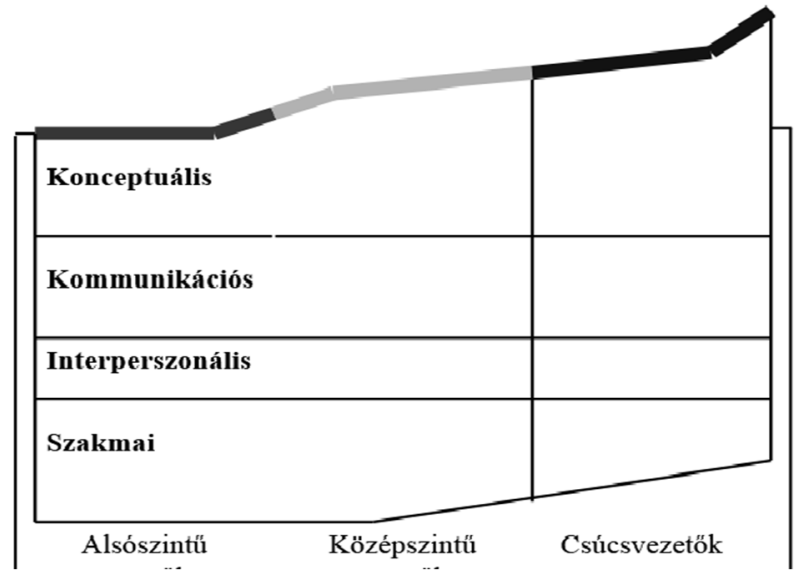

Forrás: Stocker et al., 2015

A kommunikációs készségek relatíven fontosak minden szervezeti szinten (Stocker et al., 2015). Juhász (2016) kiemeli a jó vezetői készségeket, melyeket a beosztottak elvárnak, ezek között az egészséges, fitt, jókedélyü, igazságos, megnyerő modorú mellett a jó kommunikációs készséget is nevesítették. A jó kommunikáció nélkül a konceptuális, interperszonális és szakmai képességek hozzáértő alkalmazása nem képzelhető el. A vezető legjobb ötletei és szándékai nem valósulhatnak meg hatékony kommunikáció nélkül, melyeket másoknak közvetít.

A kommunikációt két fontos tényező hatja át, a küldő és a befogadó. Lényege az, hogy egy hír, üzenet eljut a befogadóhoz. Ez csak az egyik irány. Az üzenet tartalmára való reagálás cselekvésben vagy válasz üzenetben azt mutatja, hogy megértette a küldő felet. Ez a másik iránya a kommunikációnak. Tehát kétirányú folyamatról beszélünk, amelyben a küldő és a befogadó között oda-vissza áramlik az információ. A szervezet hatékony működésének feltétele a kétirányú kommunikáció, 
ezért minden vezetőnek olyan helyzetet kell létrehoznia, amely erre lehetőséget ad. A vezetők legtöbbször meg akarnak győzni valakit (befogadót) szándékukról. Ebben az esetben fel kell használniuk a hatékony kommunikáció minden eszközét.

A civil szervezeteknél a szervezeti kommunikáció a folyamatmegvalósításban annak szervezésében és az irányításában is nagyon fontos (Bácsné et al., 2018, Bácsné 2015, Dajnoki et al., 2018). Dajnoki (2003) szerint a vezetői kommunikáció nem más, mint a vezetői feladatok megvalósításának eszköze, része a szervezeti kommunikációnak. Alapvető részét képezi a vezetői munkának (Pierog, 2013). Mintzberg (1973) szervezet nem müködhet kommunikáció nélkül, mert résztvevői nem tudnák összehangolni munkájukat, a közös cél érdekében együtt dolgozni. Nemes (1998) megfogalmazásában az információt közvetítő folyamat a kommunikáció, amely egyik embertől a másikig terjed. A szakirodalom alapján beszélünk formális és informális kommunikációs csatornákról. A formális csatornák és azok kialakításáért, karban tartásásáért függetlenül azok irányától a vezetők a felelősek (Dajnoki, 2003). Természetes úton alakulnak ki az információs csatornák a szervezetekben. A vezetők részéről nagyon fontos feladat, hogy ismerjék és biztosítsák ezeket a csatornákat a vezetésben (Kelly-Grimes, 1993).

A kutatás során a formális (hivatalos) és informális (nem hivatalos) kommunikációs formák fontosságának elbírálását külön kérdésben vizsgáltuk a szervezet vezetöinek véleménye szerint.

\section{A szervezet ismertetése}

A kutatásban vizsgált szervezet neve: Fogyatékosok Országos Diák-, Verseny- és Szabadidősport Szövetsége (továbbiakban: FODISZ). A FODISZ közhasznú társadalmi szervezetként 2008. március 8-án alakult meg azzal a céllal, hogy minden fogyatékossági ágban kialakítsa azt a struktúrát, amely lehetővé teszi a fogyatékos emberek, diák- és szabadidősport tevékenységeinek minőségi és hatékony szervezését. A FODISZ célja között szerepel, hogy biztosítsa a fogyatékossággal élő diákok számára az egészséges életmódra nevelést, a rendszeres mozgás iránti igényt, a testi-lelki és szociális fejlődésüket a sport által. Célként fogalmazódik meg, hogy ösztönözze a fiatalokat arra, hogy a sport legyen az életük szerves része, rendszeresen végezzék azt, ezért a különböző sportágak népszerüsítésében is domináns szerepet vállal. A sport által segíti a hátrányos helyzetü csoportok társadalmi felzárkózását és az esélyegyenlőség biztosítását. Egy olyan diákolimpiai versenyrendszert müködtet, amelyben a magyarországi fogyatékos diákok számára minden sérülés-specifikumban több sportágban teremt lehetőséget a sportolásra.

A szervezet a fogyatékossággal élő diákok sportolása mellett kikapcsolódási lehetőséget nyújt szabadidős és egészségmegőrző programokkal, a fogyatékos felnőttek számára is.

\section{Anyag és módszer}

A kutatásban fogyatékossággal élők sportolásával foglalkozó sportszervezet szervezeti kommunikációs és motivációs tényezőit vizsgáltuk. A kutatásban vizsgált 
szervezet neve: Fogyatékosok Országos Diák-, Verseny- és Szabadidősport Szövetsége (továbbiakban: FODISZ). A vizsgálatot a szervezet országos és megyei tagszervezeteinek szintjén végeztük. A megkérdezettek a szervezet vezetői és a megyei tagszervezetek képviselői voltak. A felmérés a szervezeti kommunikációra irányult, valamint motivációs tényezőket vizsgálta a szervezet vezetői körében. A szervezet müködésével kapcsolatos információkat mélyinterjú segítségével végeztük, illetve Pilot kutatás keretében online kérdőívezést alkalmaztunk. A szervezet tagjai e-mailben kaptak felkérést a kérdöív kitöltésére. Az anonimitás biztosítva volt azáltal, hogy a kitöltőknek nem kellett a nevüket megadni és online felületen lehetett a kitöltéseket megtenni. A felmérést 2018 júliusában folytattuk le. Az alkalmazott kérdőívet Pierog (2013) munkájából részben adaptáltuk. A kérdések között vannak feleletválasztós itemek, ahol csak egy választ lehet megjelölni, többválaszos, valamint alkalmaztunk Likert-skálát 1-5-ig terjedően. A felmérés lezárásáig összesen 40 kitöltött kérdőív került visszaküldésre, tehát a megkérdezettek 100\%-a válaszolt. A kérdőívezés mellett dokumentumelemzést is végeztünk, áttekintettük a szervezet alapító- és müködési szabályzatát, honlapját és interjút készítettünk a FODISZ ügyvezető elnökével.

A kutatásom célkitüzése, hogy képet kapjunk arról, hogy milyen kommunikációs tényezők vannak a vizsgált szervezetben. Választ kerestünk arra, hogy a megkérdezett vezetők milyen motivációs tényezőket tartanak fontosnak.

Hipotézis

- A vezetők az infokommunikációs eszközöket részesítik előnyben.

- A vezetők beosztás alapján különbség van az informális kommunikációs formák fontosságának megítélése esetében.

- a válaszadók többségénél a szakmai elhivatottság adja az elsődleges motiváltságot.

\section{Eredmények és azok értékelése}

A válaszadók szociodemográfiai jellemzői

A válaszadók nemenkénti megoszlása 67,4\%-a (26fo) férfi, 32,6\%-a (14fö) nő. Az ügyvezető elnök, országos versenyigazgató, irodavezető, kommunikációs és marketingigazgató és gazdasági vezető beosztásban egy-egy fő van, megyei képviselő 20fö, megyei versenyigazgató 20 fö. Iskolai végzettség tekintetében a férfiak 27,6\%-nak (8 fö), egyetemi és 72,4\%-nak (18 fö) föiskolai végzettsége van, míg a nőknél egyetemi végzettsége 35,7\%-nak (5 fö), föiskolai végzettsége 64,3\%nak (9 fö) van. A 1. ábra azt mutatja, hogy a válaszadók mennyi ideje dolgoznak a szervezetnél. A legnagyobb arányban, 44,3\%-uk 5-10 év között, 21,3\%-uk 3-5 év között és 19,7\%-uk 3 évnél kevesebb és 10 évnél több 14,7\%-uk ideje dolgozik a vizsgált szervezetnél. 


\section{2. ábra: A válaszadók a szervezetnél eltöltött éveinek vizsgálata}

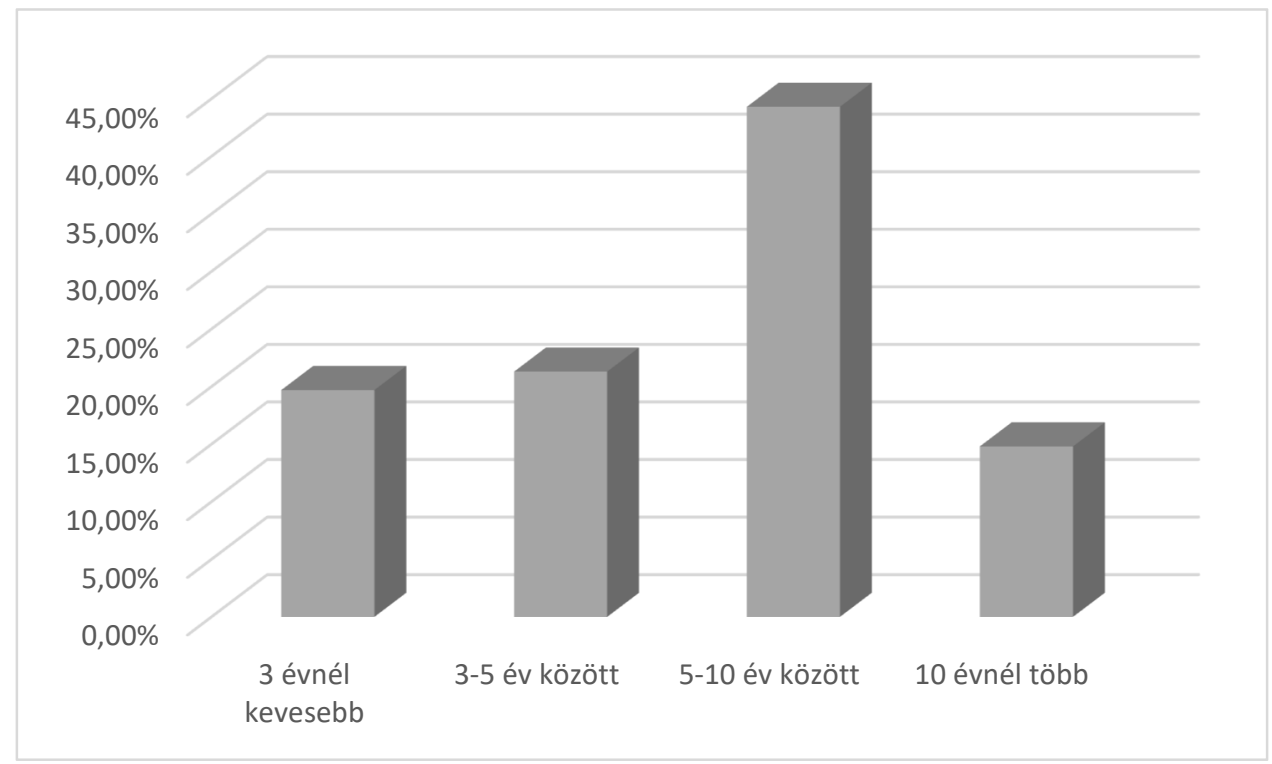

Forrás: saját kutatás

Kommunikációs vizsgálat

A megkérdezett vezetők értékelése szerint a legfontosabb kommunikációs forma a szervezeten belül a körlevelek és a megbeszélés. Likert-skálán az 5-ös értéket kapta, teljes mértékben fontosnak tartják. A válaszadó vezetők az infokommunikációs eszközöket részesítik előnyben. Leginkább körlevél és megbeszélés formájában kommunikálnak a szervezeten belül. Ez annak tudható be, hogy más- más helyszínen dolgoznak, így ez a legpraktikusabb, de viszont az eredmények alapján megállapítható, hogy minden felsorolt kommunikációs formát fontosnak vélnek. Körlevél, megbeszélés, hirdetmények, tárgyalás, értekezlet, érdekképviselet sorrendet lehet felállítani a formális kommunikációs formák értékelése alapján. Az erre vonatkozó eredményeket az 1. táblázat szemlélteti.

Az informális kommunikációs csatornákat is megvizsgáltuk a vezetők körében. A vizsgált szervezetben a vezetők összességében nem ítélik fontosnak az informális kommunikációt. Az adott formák közül a baráti beszélgetések kiemelkedőek, Likertskálán az 5-ös értéket kapta, ami azt jelenti, hogy teljes mértékben fontosnak tartják. $\mathrm{Az}$ interjúk alkalmával kiderült, hogy bensőséges kapcsolatot tartanak fenn egymással a szervezeten belül, valamint a megyei tagszervezetekkel is. Ezzel magyarázható, hogy a baráti beszélgetések fontos szerepet kapnak (2. ábra). 
1. táblázat: A formális kommunikációs formák fontosságának megítélése (1= egyáltalán nem fontos, $5=$ teljes mértékben fontos)

\begin{tabular}{|c|c|c|c|c|c|c|c|c|}
\hline \multirow{2}{*}{$\begin{array}{l}\text { Formális } \\
\text { kommunikációs } \\
\text { formák }\end{array}$} & \multicolumn{5}{|c|}{ Likert-skála } & \multirow[t]{2}{*}{ Összesen } & \multirow[t]{2}{*}{ Mean } & \multirow[t]{2}{*}{ Szórás } \\
\hline & 1 & 2 & 3 & 4 & 5 & & & \\
\hline Megbeszélés (fö, \%) & - & - & - & $\begin{array}{c}1 \\
2,3\end{array}$ & $\begin{array}{c}39 \\
97,7\end{array}$ & $\begin{array}{c}40 \\
100\end{array}$ & 4,98 & , 152 \\
\hline Hirdetmények (fő, \%) & - & & $\begin{array}{c}4 \\
9,3 \\
\end{array}$ & $\begin{array}{c}14 \\
32,6 \\
\end{array}$ & $\begin{array}{c}25 \\
58,1 \\
\end{array}$ & $\begin{array}{c}40 \\
100 \\
\end{array}$ & 4,49 & ,668 \\
\hline Körlevelek (fö, \%) & - & & & & $\begin{array}{c}40 \\
100 \\
\end{array}$ & $\begin{array}{c}40 \\
100 \\
\end{array}$ & 5,00 & ,00 \\
\hline Érdekképviselet (fö, \%) & - & & $\begin{array}{c}6 \\
14,0 \\
\end{array}$ & $\begin{array}{c}18 \\
41,8 \\
\end{array}$ & $\begin{array}{c}19 \\
44,2 \\
\end{array}$ & $\begin{array}{c}40 \\
100 \\
\end{array}$ & 4,30 & ,708 \\
\hline Tárgyalás (fö, \%) & - & $\begin{array}{c}2 \\
4,7\end{array}$ & $\begin{array}{c}16 \\
37,1\end{array}$ & $\begin{array}{c}2 \\
4,7\end{array}$ & $\begin{array}{c}23 \\
53,5\end{array}$ & $\begin{array}{c}40 \\
100 \\
\end{array}$ & 4,07 & 1,055 \\
\hline $\begin{array}{l}\text { Értekezlet } \\
\text { (fö, \%) }\end{array}$ & $\begin{array}{c}1 \\
2,3 \\
\end{array}$ & $\begin{array}{c}5 \\
11,6 \\
\end{array}$ & $\begin{array}{c}14 \\
32,6\end{array}$ & $\begin{array}{c}2 \\
4,7 \\
\end{array}$ & $\begin{array}{c}21 \\
48,8 \\
\end{array}$ & $\begin{array}{c}40 \\
100 \\
\end{array}$ & 3,86 & 1,226 \\
\hline
\end{tabular}

Forrás: saját kutatás

2. ábra: Az informális kommunikációs formák fontosságának megítélése (1= egyáltalán nem fontos, $5=$ teljes mértékben fontos)

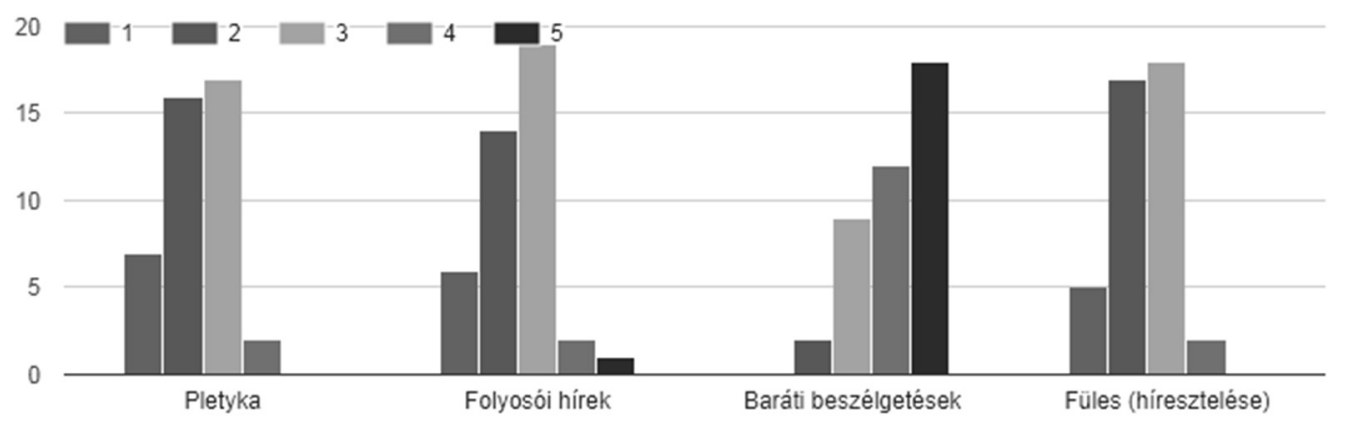

Forrás: saját kutatás

A belső kommunikációs formák vizsgálata során külön elemeztük a formális (hivatalos) és az informális (nem hivatalos) csatornákat. A formális kommunikációs eszközök esetében megállapítható, hogy összességében a körlevelezést, valamint a megbeszélést tartják a vezetők a legfontosabbnak. A megkérdezettek minősítése alapján a következő sorrendet lehet felállítani, amely körlevél, megbeszélés, hirdetmények, tárgyalás, értekezlet, érdekképviselet a formális kommunikációs formák értékelése alapján. Az informális kommunikációs formák elemzése azt mutatja, hogy a legfontosabbnak a baráti beszélgetéseket ítélték a vezetők.

A válaszadók beosztása meghatározza a folyosói híreket megítélését, szignifikáns eltérés mutatkozott ebben az esetben, chi2 $=53,291, \mathrm{Df}=24, \mathrm{p}=0,001$. A belső kommunikáció a szervezeten belül kapcsolatok kialakítására törekszik, ezáltal hat a szervezeti müködés koordinálására (Gróf, 2001). 
A külső kommunikáció minden szervezet számára meghatározó fontosságú, Dajnoki (2003) meghatározásában a vezetői kommunikációnak két lába van: külső és belső kommunikáció.

A kérdőívben arra kerestük a választ, hogy milyen jelentőséggel bírnak a szervezet müködtetése során a különböző marketingeszközök. Csoportkommunikációs, tömegkommunikációs, valamint egyéb módszereket alkalmaztunk (Pierog, 2013).

Az eredmények elemzésénél kiderült, hogy a külső kommunikációs formák fontosságának megítélésénél a szervezet vezetői a csoportkommunikációs és a tömegkommunikációs marketingeszközöket teljes mértékben fontosnak tartják. A Likert-skálán az 5-ös értéket határozták meg, de az egyéb módszerek (lobbi, támogatás, szponzorálás) megítélése is nagyon fontos szerepet kapott az értékelésnél, hiszen a Likert-skálán a 4-es értéket kapta. A 3. ábra szemlélteti az eredményeket.

Összeségében elmondható, hogy nagy szerepük van a felsorolt marketingeszközöknek a szervezet működésében.

\section{3. ábra: A külső kommunikációs formák fontosságának megítélése (1= egyáltalán nem fontos, $5=$ teljes mértékben fontos)}

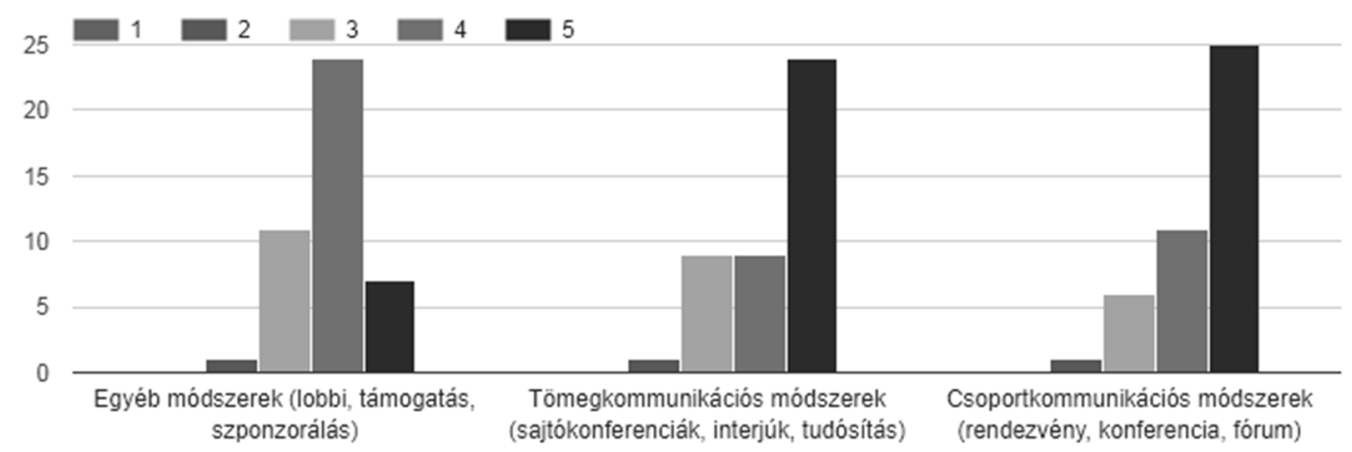

Forrás: saját kutatás

A civil szervezetek céljai között általánosan szerepel, hogy felhívják a figyelmet egy társadalmi jelentőségü problémára és megoldást javasoljanak. Emellett a tevékenységükre és létezésükre vonatkozó figyelemfelkeltés is elengedhetetlen fontosságú. A marketingkommunikáció igen nagy jelentőséggel bír a szervezetek számára. Ide tartozik minden eszköz, mellyel a szervezet kapcsolatba lép a célcsoportjával, támogatókkal, partnereivel azért, hogy bemutassa tevékenységét, kínálatát (Pierog, 2013). A civil szervezeteknek a célja nem pénzügyi eredmény, hanem az egyén és társadalom jobblétének a megsegítése.

\section{Motivációs vizsgálat}

Külön kérdésben vizsgáltuk, hogy a vezetőket mi motiválja szervezetben való tevékenységre. Az elemzés során megállapítható, hogy a válaszadók leginkább a szakmai elhivatottságot 69,8\%-ban (28 fö) és a belső késztetést 67,4\% (27 fö) helyezik előtérbe. Ezeket követi a segíteni akarás 60,5\%-ban (24 fö) és a társadalmi 
késztetés 46,5\%-ban (18 fö). A lehetőségek megszerzése 34,9\%-a (14 fö), a munkahelyi nyomás $11,6 \%$-a ( 5 fö), a családi késztetés $14 \%$-a (6 fö) és a hiányérzet 4,7\%-a (2 fö) kevésbé motiváló erő a vezetők körében. Gyakoriak azok a kutatások, melyek azt vizsgálják, hogy a vezetők hatásgyakorlásának egyik megjelenési formája, amikor ők motiválják a beosztottakat, mely egyben a vezetői stílust is determinálja (Gergely-Pierog, 2016a; Gergely-Pierog, 2016b; Piereog et al., 2017), melyet Juhász és Szabolcsi (2016) kutatásai is vizsgáltak. A vezetői stílus és kompetencia megléte a beosztottak elégedettségét növelheti (Juhász, 2015).

\section{5. Összegzés}

A belső kommunikációs formák vizsgálata során külön elemeztük a formális (hivatalos) és az informális (nem hivatalos) csatornákat. A formális kommunikációs eszközök esetében megállapítható, hogy összességében a körlevelezést, valamint a megbeszélést tartják a vezetők a legfontosabbnak. A vezetők az infokommunikációs eszközöket részesítik előnyben.

A megkérdezettek minősítése alapján a következő sorrendet lehet felállítani, amely körlevél, megbeszélés, hirdetmények, tárgyalás, értekezlet, érdekképviselet a formális kommunikációs formák értékelése alapján. Az informális kommunikációs formák elemzése azt mutatja, hogy a legfontosabbnak a baráti beszélgetéseket ítélték a vezetők. A válaszadók beosztása meghatározza a folyosói híreket megítélését, szignifikáns eltérés (chi2 $=53,291, \mathrm{Df}=24, \mathrm{p}=0,001$ ) mutatkozott ebben az esetben. A belső kommunikáció a szervezeten belül kapcsolatok kialakítására törekszik, ezáltal hat a szervezeti mủködés koordinálására (Gróf, 2001). A szervezet céljai között általánosan szerepel, hogy felhívják a figyelmet egy társadalmi jelentőségü problémára és megoldást javasoljanak. Emellett a tevékenységükre és létezésükre vonatkozó figyelemfelkeltés is elengedhetetlen fontosságú. A marketingkommunikáció igen nagy jelentőséggel bír a szervezetek számára. Ide tartozik minden eszköz, mellyel a szervezet kapcsolatba lép a célcsoportjával, támogatókkal, partnereivel azért, hogy bemutassa tevékenységét, kínálatát (Pierog, 2013). A civil szervezeteknek a célja nem pénzügyi eredmény, hanem az egyén és társadalom jobblétének a megsegítése (Pierog, 2013).

A motivációs vizsgálatok eredményei azt igazolják, hogy a válaszadók többségénél a szakmai elhivatottság adja az elsődleges motiváltságot. Az interjúk során kiderült, hogy legtöbben aktív pedagógusok is, és ezért fontos feltárni a fogyatékossággal élő személyek számára a kínálkozó sportolási és szabadidős lehetőségeket. Másodlagos eredményként 2,4\% eltéréssel a belső késztetés, valamint a segíteni akarás állapítható meg. Legalacsonyabb a lehetőségek megszerzése 34,9\%, a munkahelyi nyomás $11,6 \%$, a családi késztetés $14 \%$ és a hiányérzet $4,7 \%$.

A publikáció elkészítését a EFOP-3.6.2-16-2017-00003 Sport- Rekreációs és Egészséggazdasági Kooperációs Kutatóhálózat létrehozása projekt támogatta. 


\section{Irodalomjegyzék}

Bácsné Bába É., Fenyves V., Dajnoki K., Szabados Gy. (2018): Sportszolgáltatások kínálatának elemzése szervezeti szempontok alapján. International Journal of Engineering and Management Sciences, 3 (4): 465-474.

Bácsné Bába É. (2015): Sportszervezetek müködési kereteinek változása. Közép-Európai Közlemények, 8 (1): 151-161.

Balázs-Földi E. (2017): Fogyatékos és megváltozott munkaképességü személyekkel kapcsolatos ismeretek összehasonlító elemzése Hajdú-Bihar megye három járásában. Taylor: GazdálkodásÉs Szervezéstudományi Folyóirat: A Virtuális Intézet Közép-Európa Kutatására Közleményei, 9 (3-4): 26-34.

Balázs-Földi E., Dajnoki K. (2016a): Sajátosságok a fogyatékos és megváltozott munkaképességü munkavállalók foglalkoztatásában. Gradus, 3 (1): 313-318.

Balázs-Földi E., Dajnoki K. (2016b): Munkáltatói aspektusok feltárása a fogyatékos és megváltozott munkaképességű személyek foglalkoztatásában. Taylor: Gazdálkodás- És Szervezéstudományi Folyóirat: A Virtuális Intézet Közép-Európa Kutatására Közleményei, 8 (3): 93-103.

Block, M. E., Taliaferro, A., Moran, T. E. (2013) : Physical Activity and Youth with Disabilities: Barriers and Supports. Prevention Researcher, 20 (2): 18-20.

Bota, A., Teodorescu, S., Serbanoiu, S. (2014): Unified Sports - a Social Inclusion Factor in School Communities for Young People with Intellectual Disabilities. 3rd International Congress on Physical Education, Sport and Kinetotherapy (Icpesk 2013) 117 (2014): 21-26.

Carlon, S., Shields, N., Dodd, K., Taylor, N. (2013): Differences in habitual physical activity levels of young people with cerebral palsy and their typically developing peers. A systematic review. Disabil Rehabil., 35 (8): 647-655.

Dajnoki K. (2003): Szervezeti kommunikáció. In: Berde Cs. (szerk.): Vezetéselméleti ismeretek. Debreceni Campus Kht., Debrecen. 102-111.

Dajnoki K., Szabados Gy. N., Bácsné Bába É. (2018): A Case Study on Human Resource Management Practice of a Sport Organization. International Journal of Engineering and Management Sciences, 3 (4): 410-425.

Frey, G., Stanish, H. I., Temple, V. A. (2008): Physical activity of youth with intellectual disability. Review and research agenda. Adapt Phys Activ Q., 25 (2): 95-117.

Gergely É. , Pierog A. (2016a): Motivációs tényezők feltárása civil és profitorientált szervezeteknél. GRADUS, 3 (1): 368-373.

Gergely É., Pierog A. (2016b): Vezetőkkel szembeni elvárás-vizsgálatok egyetemisták körében. Taylor: Gazdálkodás- És Szervezéstudományi Folyóirat: A Virtuális Intézet Közép-Európa Kutatására Közleményei, 8 (2): 64-71.

Gombás J. (2016): Budapesten élök 18-65 év közötti látássérült személyek szabadidö-sportolási szokásainak és szabadidösport látássérültek számára akadálymentes hozzáférésének vizsgálata. Doktori értekezés. Testnevelési Egyetem, Budapest. <http://real-phd.mtak.hu/467/19/ gomb\%C3\%A1sjudit. d.pdf>. (2018.07.12.)

Gróf A. (2001): A vállalat kommunikációs kapcsolatrendszerének szerepe. Marketing és menedzsment, 35 (4): 25-31.

Johnson, C. C. (2009): The Benefits of Physical Activity for Youth With Developmental Disabilities. A Systematic Review. American Journal of Health Promotion, 23 (3): 157-167.

Juhász G. (2012): Szervezési és Vezetési Alapismeretek. Pécsi Tudományegyetem Bölcsészettudományi Kar Szociális Munka és Szociálpolitika Tanszék. Pécs. <http://reflektiv.hu/egyeb/digitalis/szervezesi_es_vezetesi_alapismeretek.pdf >. (2018.10.01.)

Juhász Cs. (2016): Kommunikációs elvárások a szervezetben. Taylor: Gazdálkodás- És Szervezéstudományi Folyóirat: A Virtuális Közép-európai közlemények, (9) 2: 124-133.

Juhász Cs., Szabolcsi S.: (2016): A vezetői stílus vizsgálatának egy lehetséges módszere. Taylor: Gazdálkodás- És Szervezéstudományi Folyóirat: A Virtuális Intézet Közép-Európa Kutatására Közleményei, 9 (1): 55-61. 
Juhász Csilla (2015): Az elégedettség és a motiválás gyakorlati összefüggései. Taylor: GazdálkodásÉs Szervezéstudományi Folyóirat: A Virtuális Intézet Közép-Európa Kutatására Közleményei, 7 (3-4): 215-221.

Kelly, A., Grimes, T. (1993): A menedzsment elvei. Acca Hngary Kft., Budapest.

Kissow, A. M. (2015): Participation in physical activity and the everyday life of people with physical disabilities. A review of the literature. Scandinavian Journal of Disability Research, 17 (2): 144166.

KSH (2014): 2011. Évi Népszámlálás - 11. Fogyatékossággal élők. Központi Statisztikai Hivatal, Budapest.

Laczkó T., Rétsági E. (2015): A sport társadalmi aspektusai. PTE, Pécs.

LeMura, L., Maziekas, M. (2002) : Factors that alter body fat, body mass and fat-free mass in pediatric obesity. Med Sci Sports Exerc., 34 (3): 487-496.

Lőrincz B., Pajor E., Gombás J. (2015): A Vakok Általános Iskolájában, Speciális és Speciális Szakiskolájában tanuló 10-17 éves látássérült fiatalok motoros képességeinek vizsgálata az Eurofit teszt alapján. Magyar Sporttudományi Szemle, 16 (4): 4-10.

Mintzberg, H. (1973): The Nature of Managerial Work. Prentice Hall, Englewood Cliffs, N.J.

Mintzberg, H. (1988): The Effective Organization. Forces and Forms. McGill University Faculty of Management.

Nemes F. (1998): Vezetési ismeretek és módszerek. BKE Vezetőképző Intézet, Budapest.

Nemes F. (2006): Szervezet és Vezetés. Budapesti Corvinus Egyetem, Budapest. <https://dea.lib.unideb.hu/dea/bitstream/handle/2437/78159/de_2630.pdf>. (2018.09.14.)

Oktay, K., Mehmet, D., İzzet,. U., Şıhmehmet, Y. (2015): The importance of sports for disabled children. Merit Research Journal of Art, Social Science and Humanities, 3 (5): 58-61.

Osváth P. (2004): A fogyatékosság ügyének megjelenése a sporttudományban. Magyar Sporttudományi Szemle, 5 (4): 44-46.

Pierog A. (2013): Civil szervezetek vezetési és müködési sajátosságai. Doktori értekezés, Debrecen. <https://dea.lib.unideb.hu/dea/bitstream/handle/2437/177014/Pierog_Anita_disszertaciot.pdf?s equence $=8>$. (2018.08.13.)

Pierog A., Bácsné Bába É., Dajnoki K. (2017): Sikeres vezetők tulajdonságainak feltárása a Debreceni Egyetem Gazdaságtudományi Kar hallgatói körében végzett kutatás eredményei alapján. Taylor: Gazdálkodás- És Szervezéstudományi Folyóirat: A Virtuális Intézet Közép-Európa Kutatására Közleményei, 9 (1): 94-100.

Sáringerné, Sz. Zs. (2014). A fogyatékkal élők sportolási lehetőségei. In: Dóczi, T., Gál, A., Sáringerné Sz. Zs. (szerk.): Társadalmi befogadás a sportban és a sport által (szociális inklúzió), Budapest. 93-113.

Shapiro, D. R., Martin, J. J. (2010): Athletic identity, affect, and peer relations in youth athletes with physical disabilities. Disability and Health Journal, 3 (2): 79-85.

Stocker M., Ács P., Farkas F. (2015): Stratégiaalkotás, Szervezés és Vezetés a Sportban. In: Ács P. (szerk.): Sport és Gazdaság. Pécsi Tudományegyetem Egészségtudományi Kar, Pécs. 40-93.

Tóthné Kälbli K., Gombás J. (2016): A sport hatása a fogyatékossággal élő személyek életminőségére. In: Hamar Pál (szerk.): A mozgás mint személyiségfejlesztő tényező. Eötvös József Könyvkiadó, Budapest. 115-141.

WHO - World Bank (2011): World report on disability. <http://www.who.int/disabilities/world_ report/2011/report.pdf> (2018. 02. 21.) 